\title{
地方自治体諸施設の運用段階における省エネ・省資源管理の実態調査研究
}

\section{A SURVEY ON MANAGEMENT OF ENERGY AND RESOURCES-SAVINGS IN THE OPERATION OF LOCAL GOVERNMENTS' FACILITIES}

\author{
三由 賢*, 村上公哉**, 尾島俊雄*** \\ Ken MIYOSHI, Kimiya MURAKAMI and Toshio OJIMA
}

\begin{abstract}
In order to reduce the emission of $\mathrm{CO}_{2}$ and other reactive gas, it is necessary for our local governments to take effective actions to set an example not only for the citizens but also for private enterprises in each governing area. Recently, "Environmental Management System" has been introduced as one of the effective ways to reduce the impact against the environment by all kinds of activities, including the operation of buildings. There are movement in some of the local governments to take the steps so called "PDCA cycles" in order to carry out the energy savings and economizing resources in the operation of local government's facilities, as one of the management systems.

In this study we have conducted a research on local governments in Japan that hold population of more than 100,000 and discovered that there were several flaws in each steps of the present management systems.
\end{abstract}

Key Words: Local Government, Operation, Management System, Energy \& Resources-Savings 地方自治体、運用段階、管理システム、省エネルギー・省資源

\section{1.はじめに}

我が国において二酸化炭素やその他の污染ガス排出量の抑制を実 行するにあたって建設部門に対する期待が大きい。特に建築生涯に お汁る各段階の排出量を比較すると運用段階における排出量の割合 が高く、効果的な対策が望まれている。これを受けて建設省では「環 境配慮型官庁施設計画指針」の発表に引き続き既存の施設に関する 取り組み手法の指針を現在作成中であり、また、環境庁では具体的 な取り組みの指針として「国の事業者・消費者としての環境保全に 向けた取組の率先実行のための計画」を発表している。これらは関 倸省庁にとどまらず、我が国全体における実施に役立てることが期 待されており、特に全国の地方自治体では中央官庁と同様に地域の 市民や事業者に対して先導的にこれらに対して取り組むことが望ま れる。このことからも 1998 年 4 月には「地球温暖化対策の推進に 関する法律案」が閣議予定されている。この中で我が国の地方公共 団体においては自らの事務及び事業に関し、温暖効果ガスの排出抑 制等のため実行すべき措置について定める計画である「実行計画」 を策定し公表すること及びその赛施状を公表することが義務づけら れている。

地方自治体における環境問題に関わる施策には、従来の地域に密 着した公害対策から地球規模の環境問題までと炎の項目は広範囲に
及んでいる。近年、多様な施策の中で地方自治体が保有する諸施設 における省エネルギー・省資源管理（省エネ・省資源管理）に積極 的に取り組む自治体が増えてきている。その背景の一つには地方自 治体がその地域においてエネルギーを大量に消費する事業者である ことがある。例えば、図 1 に人口約 10 万人規模の地方自治体であ るA市の行政区域内に存在する全建物が消費する年間電力量の中で、 市が保有する諸施設が消費する割合を示す。電力消費量は 1997 年 度実績値から市が試算したものである。市域の全建物の消費量は電 気事業者のデータであり、市が保有する諸施設の消費量は市のデー タである。本研究では、一般施設とは庁舎、学校、保育所・幼稚園、 福祉施設、文化センター等の建築物的施設を、基盤施設とは水道、 下水道、清掃工場等の供給処理施設を意味している。これによると 市が保有する諸施設のうち、一般施設のみで約 $7 \%$ を、基盤施設を 加えると約 15\%を占めている。これによると自治体が保有する諸施 設のうち自治体一般施設だけでも全体の7\%を占めており、さらに基 盤施設を加えると約 $15 \%$ もなることがわかる。

また、こうした省エネ・省資源管理の方法として、諸施設の運用 段階におけるエネルギ一消費、水消費、下水排出、廃棄物排出の抑 制等の具体的な目標値を設定して、その目標を達成するために努力 をしようとする地方自治体が增えてきている。従来、地方自治体の

\footnotetext{
$*$ 侏日建設計 工修

**芝浦工業大学工学部建築工学科 助教授・工博

*** 早稲田大学理工学部建築学科 教授・工博
}

Nikken Sekkei Ltd, M. Eng.

Assoc. Prof., Dept. of Architecture Engineering, School of Engineering, Shibaura Institute of Technology, Dr. Eng.

Prof., Dept. of Architecture, School of Science and Engineering, Waseda University, Dr. Eng. 


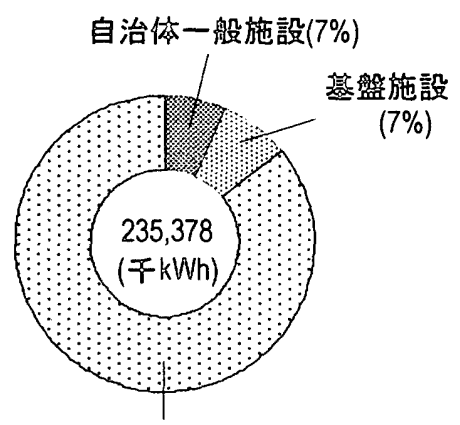

自治偷施設以外 $(86 \%)$

图1 A 市における年間電力消費量の内訳

施設における省エネルギー・省資源を考虑した場合、省エネ㟝断な どの個々の施設が建物単体で（もしくは担当部局単位で）対策を取 られていたと思われる。これに対して地方自治体の保有する施設数 が非常に多いことと、それらの管轄が複数の部署にわたっているこ とを考虑すると、施設を一元的に管理し、個々における対策の前段 階としてその自治体全体としての現状把握と具体的な対策方法を作 成することが効果的であると思われる。その考えを迸入した自治体 は、新潟県上越市等のように国際規格である IS014001 の取得に忘 じて日常業務に取り入れたり、あるいは独自の率先実行計画等の計 画にその考え方を迸入している自治体もある。この管理方法は、Plan $($ 目標設定） $\rightarrow$ Do（目標に向けて実行） $\rightarrow$ Check（実施状況の確 認） $\rightarrow$ Action（次の実施に移行する）である PDCA サイクルに基づ いた方法であり具体的には以下のような流れになる。（図 2)

P) 使用量に対する削减量などの目標值を設定し、D) 各施設におけ る実績值（数值データ）を一元的に収集することにより把握し、C) 収集した数值データを診断することにより設定した目標值に対する 達成状況を確認し、A)診断結果を諸施設にフィードバックする

本研究では、地方自治体の諸施設の「省エネ・省資源管理」にお けるこのような PDCA サイクルの流れを体系化したものを省エネ. 省資源管理システム」と呼ぶ。

しかし上記のような管理システムを導入する場合、管理対象施設 数が增え、かつ管轄組識が多分化する程、管理データ虚とその流れ が複雑となり「省エネ・省資源管理シスラ゙ム」の構筑と運用が困難 になると考えられる。そこで本研究は、保有する施設数が非常に多 く、かつそれらの管轄が複数の部署にわたっている地方自治体にお いて、現在(1)「省エネ・省資源管理システム」がどの程度構筑され ているか、(2)「省エネ・省資源管理シスデム」において諸施設の数 值データがどのような方法で流れているか、(3)上記の方法で数值デ 一タが円滑に流れるためにはどのような課題があるか、等の 3 つの 事項を実際に地方自治体を対象に調查することによって明らかにし、 今後の地方自治体における「省エネ・省資源管理シスデム」の尊入 と運用手法に役立てることを目的とした。

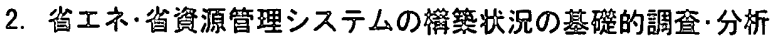
2.1 調亶微要

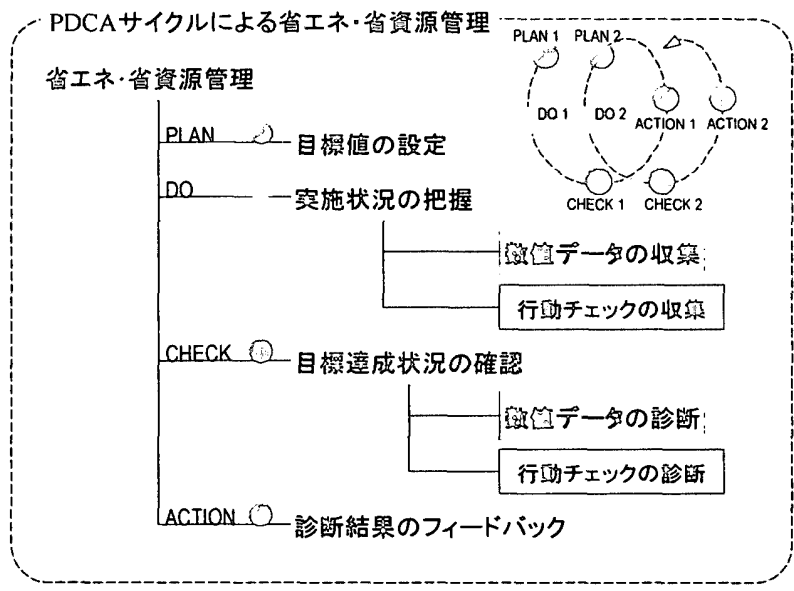

图2 PDCA サイクルによる省エネ・省資源管理の流れ

1998 年 10 月に全国自治体の平均的な省エネ・省資源管理シスデム の構築状況を把握するために全国の人口 10 万人以上の地方自治体 ; 217 市（1995 年度市勢図会）を対象にアンケート形式の調査（1 次 調査）を行った。調査内容は主に以下の項目とした。

・保有施設の用途及び各々の施設数

・主に取り組んでいる環境問題に対する施策

・管理システムム対する意識・意向

・以下における省エネ・省資源に関する取り組み状況

施設用途別…庁舎施設、出先機関、公共施設など

取組項目別…電力、都市ガス、水などの使用量・排出量

有効回答自治体は 105 市であり有効回答率は約 $50 \%$ であった。回 答者の所属部課はほとんどが環境保全に関わる部署であった。

\section{2 調盗結哭}

\section{2.1 平均保有施設致}

有効回答自治体の人口規模と保有施設数との関係を図 3 に示す。 一般に人口規模が大きくなればそれに伴い施設数が增加することが わかった。更に人口 100 万人以上の地方自治体における平均保有施 設数は 800 施設を超えることがわかり、民間事業者やその他の組識 と比較して地方自治体が一般に多くの施設を保有していることがわ かった。

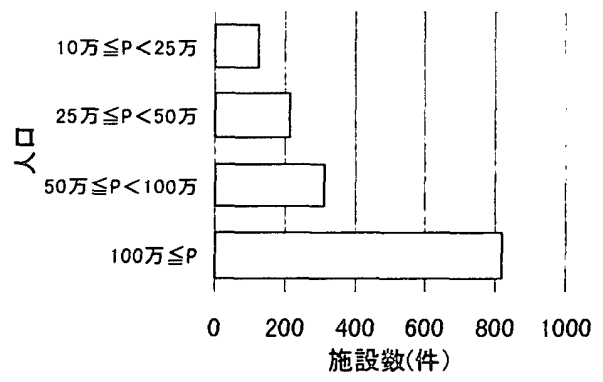

国3 自治体規模と平均保有施設数

\subsection{2 省エネ・省資源管理システムの權筑状況}

省エネ・省資源管理システムの構築状況を図 4 に示す。「既に構 築されている」約 $7 \%$ 、「現在構築中・作成中」約 $9 \%$ であり、全体 
的には省エネ・省資源管理システムが構築されている自治体は少な い。しかし「検討中」，が約 $51 \%$ り、今後地方自治体における省エ ネ・省資源管理シスデムの構築は推進されると考えられる。

本設問は、図 2 に示す PDCA サイクルに基づく省エネ・省資源管 理システムの構築状況としての設問であった。しかし管理対象施設 用途、管理取り組み項目、データの把握及び確認の内容の程度等の 回答内容から自治体によって省エネ・省資源管理システムの捉え方 は異なっていた。自治体における省エネ・省資源管理システムの構 築は始まったばかりと考えられる。

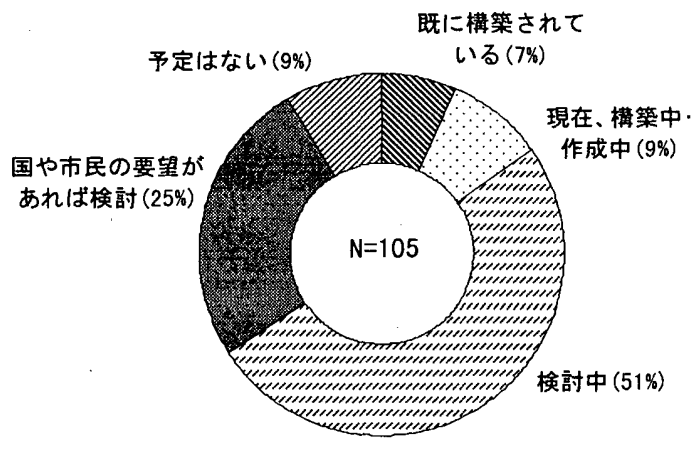

図 4 省エネ・省資源管理システムの構築状況

\section{2.3 省エネ・省資源管理における PDCA 実施状況}

省工ネ・省資源管理における PDCA の各段階をどの程度害行してい るのかを施設用途別及び項目別に調査した結果を図 5、図 6 に示寸。 PDCA サイクルのうち、P（Plan）にあたる「取り組み項目」と「目 標值の設定」、D（Do）にあたる「データ把握」、C（Check）、にあ たる「達成状況の確認」はある程度実施されていた。しかし A (Action) にあたる「診断及びそのフィードバック」についてはほ とんどの自治体で実施されていない状況であった。そして統計処理 に值する回答が得られなかったため、本分析では「診断及びそのフ イードバック」に関する分析は除外した。

図 5 によると施設用途の中では庁舎施設に関しては約 $36 \%$ 自治 体が何らかの取り組みを行っており、他の用途が約 $20 \%$ 前後である のに対して割合が高い。しかし「目標値の設定」・「データの把握」・ 「達成状況の確認」に関してはどの施設用途においてもその割合が 半減しており省エネ・省資源管理の「達成状況の把握」までの一連 の流れが実行されている自治体は施設用途とは関係なく少ない。図

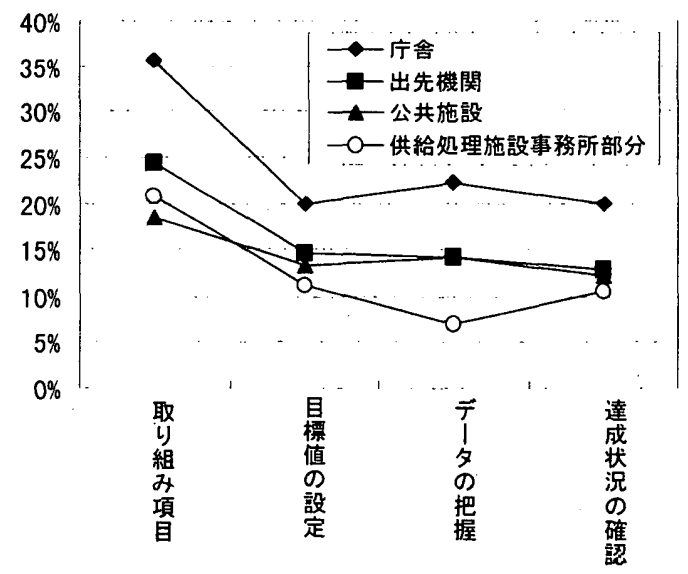

図 5 施設用途別省エネ・省資源管理の実施程度

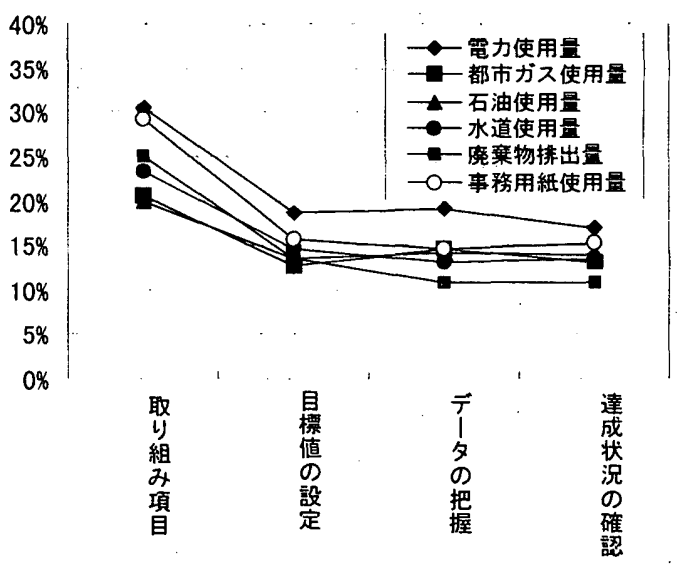

図 6 取り組み項目別省エネ・省資源管理の実施程度

6 の取り組み項目別では電力使用量や事務用紙使用量などが相対的 に各段階で頻度が高く、逆に廃棄物排出量等は頻度が低い。これは 廃棄物排出量が数量的に把握し難いことによるものと考えられる。 全体的な傾向としては施設用途別の結果と同様に取り組み項目とは 関係なく省エネ・省資源管理における PDCA の実施程度は低い。

\section{3. 省エネ·省資源管理システムの構築·運用時における課題調査}

\section{1 調査概要}

前章で明らかになったように、全国平均的に「省エネ・省資源管 理」における PDCA サイクルの実施程度が低いという現状の要因を 考察するために 1 次調查で一般的な管理シスデムもしくは「省エネ・ 省資源管理」が比較的実施されていると判断された 23 自治体に対 して、1998 年 12 月に 2 次調査を行った。調査内容は主に

・既存の管理システムの有効性に対する意見

・現状の「省エネ・省資源管理」におげる課題・問題点 の 2 項目とした。また、調查はアンケート形式で行い、有効回答自 治体は 23 自治体中 21 自治体であり、有効回答率は約 $91 \%$ だった。

\section{2 調査結果}

\section{2.1 既存管理システムの有效性}

各自治体における既存の管理システムムに対する意見をまとめたも のを図 7 に示す。有効回答の内全ての自治体において管理システム が自治体にとって有効であると考えられており、今後他の自治体に おいても構筑するべきであるとしている。しかし 7 割を超える自治 体が既存のシステムに対して有効に機能しているとは回答していな いことから、有効に機能しているかどうかの判断を客観的に判断す る数值データが存在しなかったり、実際にシステムの運用方法に課 題や問題点があることなどが考えられる。

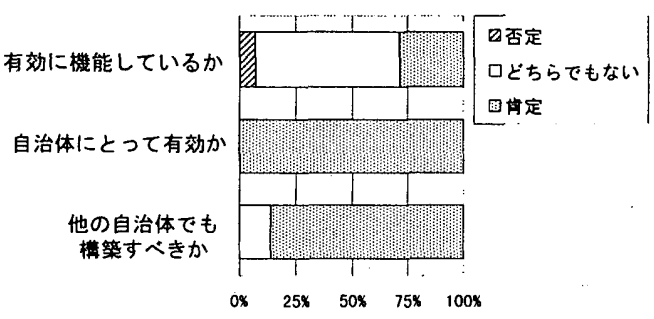

図 7 省エネ・省資源管理システムに関する意見 


\section{2 .2 省エネ・省資源管理における課題・問題点}

図 8 には省エネ・省資源管理シスラムを構築する際あるいは運用 する際に発生する課題や問題点の項目別頻度を調査した結果を示す。 組織体制上の課題·問題点として「複数部局間の連携·調整」や「複 数部局における意義の浸透・理解が困難である」が約 6 割の自治体 で発生している。また自治体内における数值データの流れと関係す る項目として「管理システムの項目の設定」・管理システムの目標 值の設定」・各保有施設のデータの把握」などが高い頻度を示した。

これらは基本的に地方自治体の諸施設の使用や管理が管轄部署ご とに分かれ、統括管理する形態を構筑することの困難さに起因する。 今後、統括組織の構築と、上記課題・問題点を改善していくことに より「省エネ・省資源管理シスデム」そのものがより有効に機能し ていくと考えられる。

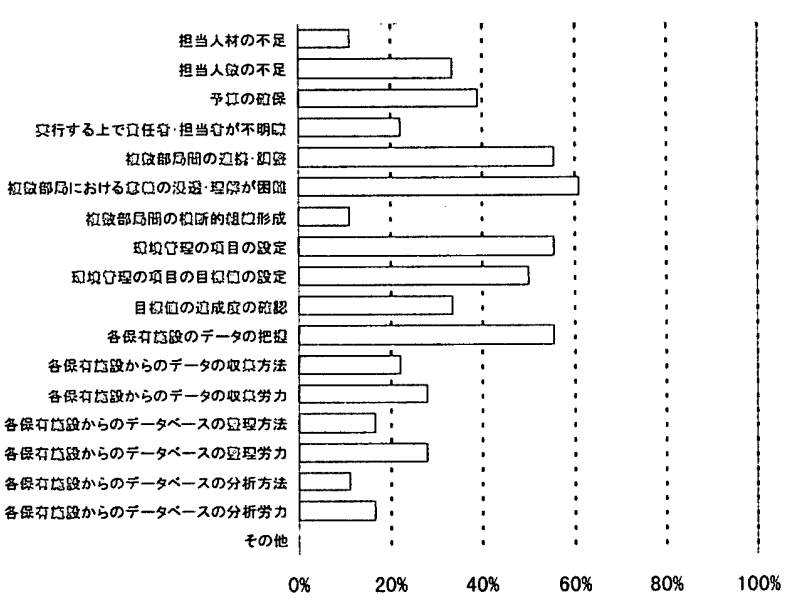

図 8 省エネ・省資源管理における課題・問題点

4. 先進自治体における省エネ・省資源管理システムに関するヒア リング調亘

\section{1 調疽概要}

本調查（3 次調查）は 2 次調查で明らかになった省エネ・省資源管 理における課題・問題点の改善方法を考察することを目的として行 った。そのため比較的頻度の高かった課題・問題点の要因を明らか にするために 1 次調查において省エネ・省資源管理が特に充実して いた先進自治体の中から対象自治体を抽出し省エネ・省資源管理シ ステムの詳細についてヒアリング調查を行った。調査対象自治体は 1. 東京都北区（1999 年 1 月 6 日）、2. 東京都昭島市（1999 年 1 月 7 日)、3. 東京都世田谷区 (1999 年1月 11 日)、4. 大阪府簧面市 (1999 年1月 14 日)、5. 京都府京都市（1999 年 1 月 14 日）の 5 つの自治 体である。1 次調査の有効回答 115 自治体の中には、これら以外に も先進自治体（例えば上越市、板橋区等）はあったが、調查時期に 協力が得られなかった。ヒアリング対象者は省エネ・省資源管理シ ステムの運用を業務内容の一つとしている担当者、つまり統括組織 内の担当者である。調查内容は各自治体のシステムにおける PDCA サイクルの流れを把握するために主に以下の項目とした。

・「省エネ・省資源管理システム」を導入することに至った経緯

・自治体としての目標値の設定有無、その内容
・保有施設の収集しているデータの内容

・保有施設のデータの収集方法やその頻度

・保有施設のデータの収集度合いやデータの使用方法

・システムム関わる職員の業務内容とその役割分担

・シスデムの効果やそれに対する意見・意向

また、これを中心に各自治体において特異とされる事項に関して 詳細にヒアリングを行った。

\section{2 各調疽対象自治体におけるシステムの概要}

\section{2.1 票京都北区}

東京都北区では 1998 年 4 月に「省エネ・省資源管理システム」 が構築され、現在、生活環境部環境課が統括管理部局としてシステ ムの運用を行っている。システムの対象となっている施設は庁舎施 設と廃棄物管理責任者が設置されている施設であり、庁舎における 各課およびその他の各対象施設にシステム運用の責任者として「環 境リーダ」を設けている。実施状況の把握内容は各「環境リーダ」 がその所轄内における実施状況を A〜D 評価によって自己評価する 「環境行動配慮点検表」であり、これを四半期ごとに収集している。 収集された情報はシステムの運用委員会である「地球環境問題検討 会」にて確認され、必要に応じて推進体制を見直している。

\section{2.2 妻京都昭島市}

東京都昭島市では 1997 年 2 月に新本庁舎が竣工し移転し、それ と同時に本庁舎の一ヶ月の電力使用量は移転前の約 2.6 倍の、ガス 使用量は約 20 倍と増大している。このことをきっかけに同市では 1998 年 7 月から「昭島市庁内エコプラン」を実施している。計画の 主な内容は「物品の購入と使用」、「ごみ减量の推進」、「省エネ・省 資源の推進」などであり、それぞれの項目に対して具体的な取組を 示しており目標値を設定している。本計画は総務部庶務課が運用し ているが具体的な実施状況は定量的には把握していない。

\section{2.3 車京都世田谷区}

東京都世田谷区では 1997 年 4 月に「世田谷区環境行動指針」を 設置し、その中で「区の率先実行計画」を設けておりこの中に具体 的な目標值を示している。また本計画には PDCA サイクルの考え方 を取り込んでおり翌年(1998 年)には区の代表的な 100 施設を「環境 行動モデル課・事業所」と位置づけてその実施状況を調査している。 報告内容は主観によって実施状況を採点するチェックシートと共に 電力使用量などの数値ブータも扱っている。報告は各課や施設の担 当者である「環境マネージャー」が四半期ごとに行っており、収集 及び集計は計画の事務局にあたる環境部環境課が行っておりその結 果は報告書形式で公表されている。

\section{2.4 大阪府簣面市}

大阪符筫面市では 1996 年 7 月に「環境に配慮した施設運営ガイ ドライン及びアクションプラン」を設置し、それに従って計画の事 務局に当たる市民生活部環境保全課が 3 ヶ月に 1 回の頻度で実施状 況を把握するための「環境配虑カルテ」を各施設（あるいは各課） の「環境配慮担当者」から収集している。（図 9）実施状況の把握の ために収集しているデータは進捗状況に対する意見や自己評価と共 に数值データである。環境保全課ではこれを集計し、1 年に 1 回各々 の「環境配虑担当者」に集計したものを返却している。

\section{2.5 京都府京都市}

京都府京都市では 1998 年 4 月に市としての嵩行計画である「京 


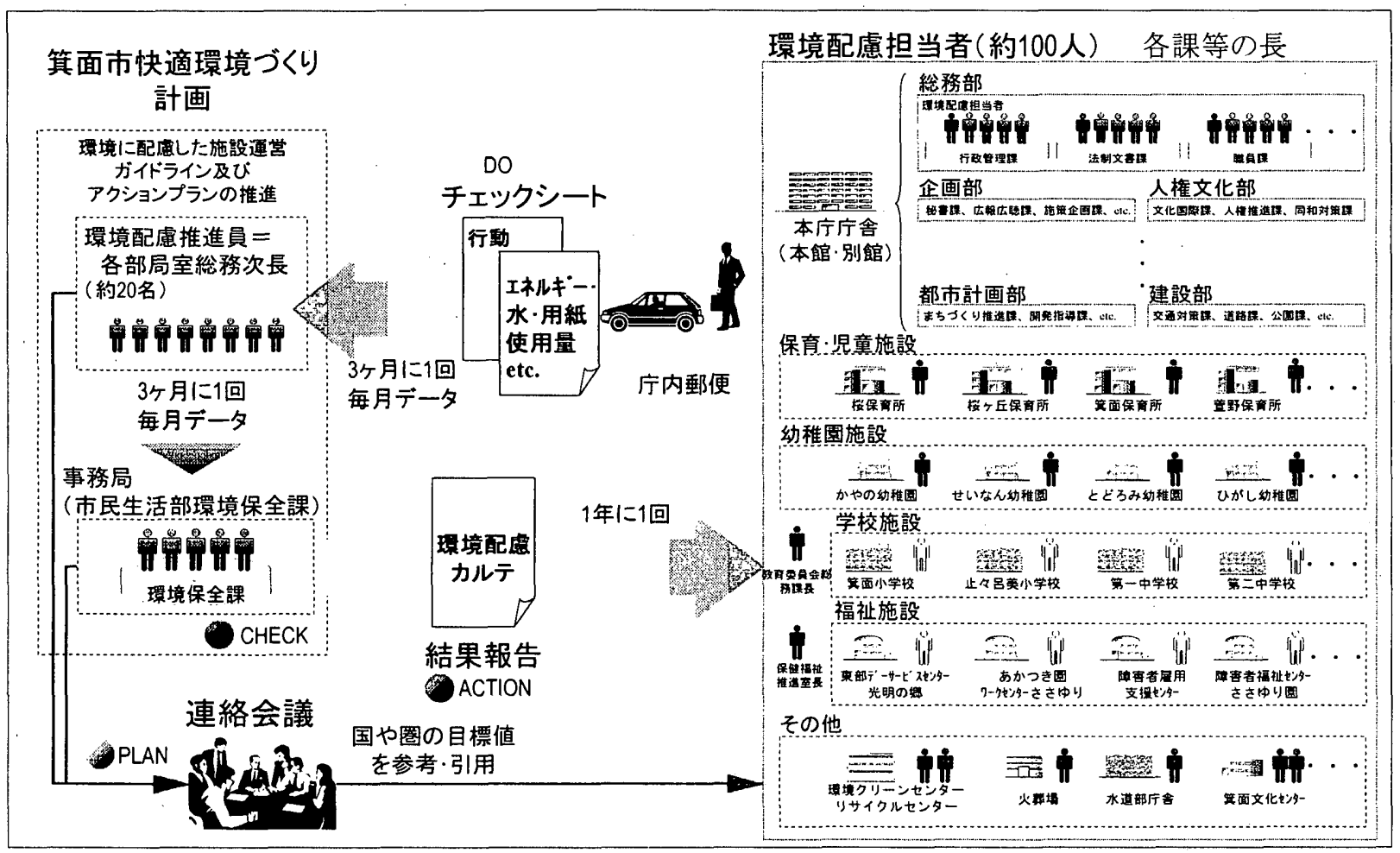

図 9 筫面市における省エネ・省資源管理システムの概要

都市役所エコオフィスプラン」を作成している。同市ではその一昨 年前に「気候変動に関する国際連合枠組条約第 3 回締約会議 (COP3 京都)」が開催されたこともあり、市が市内有数のエネルギーの大 消費者であることを認識しており計画の効果を望んでいる。計画の 実施状況を把握する手段として同市ではその規模からも事務局（環 境局環境企画部地球環境政策課）に直接報告する担当者（率先実行 統括員）は各局や区役所などに限っており、その総人数は約 35 人 に留まっている。各「率先実行統括員」はその管轄内の全ての事業 所における数值ブータを報告すると共にその実施状況をチェックリ ストにて報告している。収集された報告内容は「奏施状況調查結果 報告書」として庁内の一部の関倸者に配布されている。

\section{3 省エネ·省資源管理システムの概要}

表 1 には上記のヒアリングによって明らかになった各先進自治体 における省エネ・省資源管理システムを構成する各要素を示す。ま た、以下にその概要をシステムの段階(PDCA)ごとに説明する。

\subsection{1 目標值の設定}

一次調査の結果より大抵の省エネ・省資源管理シスデムが構筑さ れている自治体においては各行動項目に対して目標值を設定してい ることが明らかになった。その多くは自治体が保有する全施設の総 量を基準年度比で目標年度までに一定割合削减するという内容のも のであり、削減割合は国や都道府県などのそれを参考・引用したも のであった。本調査で対象になった 5 自治体においても基本的には 同様の方法で設定している。

\section{3.2 実施状況の把握}

調查対象自治体の全ての自治体において実施状況の把握の方法と して各担当部局等の小単位に各々の所轄担当部局における実施状況 を把握する統括組識に報告する担当者を設置している。その小単位
にあたる組識は自治体によって異なり、各課単位に設置しているこ とが最も多いが、箕面市のように自治体によっては各施設に設置し ている。担当者の人数もその単位の決め方や自治体規模によって異 なっている。

報告内容は大きく分けて二種類ある。一つは日常の業務活動にお いて「冷暖房の適切な温度設定を心がけているか」や「両面コピー を心がけているか」などの環境行動項目に対して出来・不出来を報 告担当者が主観的に点数評価するものである。もう一つは実際の数 値ラ゙ータ（電力使用量などの実績値）である。後者の数值データの 把握に関しては一部の自治体でのみ実施されており、更に全ての保 有施設における数值データを把握している自治体は箕面市と京都市 に限られた。また、数值ブータの項目は 1 次調查の結果と同様に電 力使用量や水道使用量などの事業者の伝票により容易に把握できる データは多くの自治体で把握されているが廃棄物排出量などのデー タに関しては把握できていない。

数值ブータの単位期間も自治体により異なっているが月間より長 い期間で把握している自治体においても月間ベースで把握すること は不可能ではない。報告の頻度は 4 半期に一回程度の自治体が多い。 全ての自治体において実施状況の報告は紙面状のものが庁内郵便に て統括組識に報告されている。一般に数值データの単位期間や報告 の頻度はより小さいものの方がデータとして価值があると考えられ るが、報告の回収やその後の処理にかかる労力を考慮にいれると調 查結果程度が妥当であると多くの自治体では認識されている。

\section{3.3 目標達成状況の確認}

数值ブータを回収している自治体において、回収された数值デー 夕は年間総和を算出する処理などの自治体全体としての現状集計が 一般に成されている。(例外として箕面市においては各施設ごとに 
饻 1 先進自治体における省エネ・省資源管理システムの構成要素

\begin{tabular}{|c|c|c|c|c|c|c|c|c|c|c|c|c|c|}
\hline & ᄉㅁ & 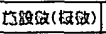 & 明蛞時胡 & 奶告の担当者 & 人转 & 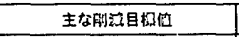 & 䡑告の内容 & テータの些位期间 & 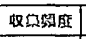 & 收运手段 & D诰钧告 & 드수的告対口 & 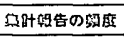 \\
\hline 北区 & 329.431 & 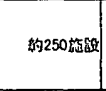 & H10年4月 & 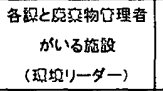 & 约80名 & 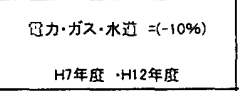 & 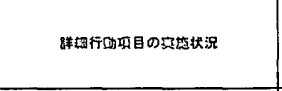 & 每44的 & 3ヶ月1に回 & 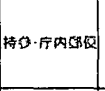 & - & - & - \\
\hline \multirow[b]{2}{*}{ 世田谷区 } & \multirow[b]{2}{*}{758.267} & \multirow[b]{2}{*}{ 敬500t5 } & \multirow[b]{2}{*}{ H9年4月 } & \multirow[b]{2}{*}{ 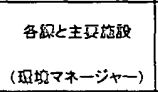 } & \multirow[b]{2}{*}{ the 380 名 } & \multirow[b]{2}{*}{ 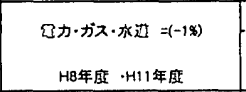 } & 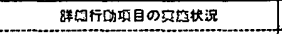 & 科44期 & \multirow[b]{2}{*}{ 3ヶ月にに回 } & \multirow[b]{2}{*}{ 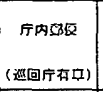 } & \multirow[b]{2}{*}{ 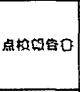 } & \multirow[b]{2}{*}{ 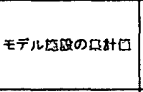 } & \multirow[b]{2}{*}{ 4年11回 } \\
\hline & & & & & & & 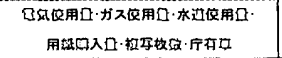 & (衣迅は2ヶ月に二回) & & & & & \\
\hline 昭的市 & 106.357 & 粕130t589 & H10年4月 & $\begin{array}{c}\text { 各部や路の医猪担当 } \\
(\rightarrow)\end{array}$ & - & 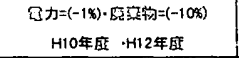 & 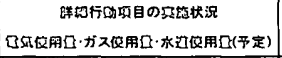 & 年間 & 年閌 & 户内内人 & - & - & - \\
\hline \multirow{2}{*}{ 政面市 } & \multirow{2}{*}{122,265} & \multirow{2}{*}{ 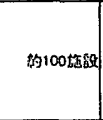 } & \multirow{2}{*}{ H8年7月 } & & \multirow{2}{*}{ 的100名 } & 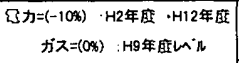 & 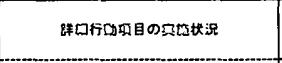 & 每4半胡 & \multirow{2}{*}{ 3ヶ月に二1回 } & \multirow{2}{*}{ 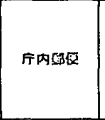 } & \multirow{2}{*}{ 回坛力ルテ } & \multirow{2}{*}{ 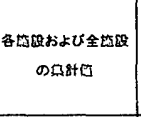 } & \multirow{2}{*}{ |年1=1回 } \\
\hline & & & & 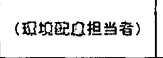 & & 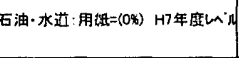 & 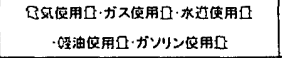 & (水进将2 月月明 & & & & & \\
\hline 京都市 & $1,389.342$ & 1. $1.000+5$ & H10年4月 & 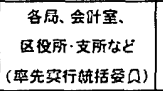 & 蚫35名 & 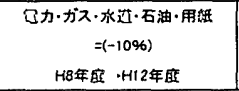 & 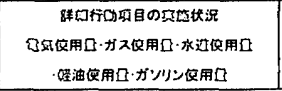 & 年明 & 1年に回 & 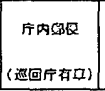 & 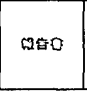 & 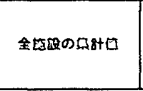 & 1利1回 \\
\hline
\end{tabular}

経年変化がわかる集計報告形式を採用している。）また、その集計 結果と数值目標を照らし合わせることによる省エネ・省凟源の実施 状況の把握をしている。

\subsection{4 診断結菆のフィードバック}

一部の自治体では、集計されたデータを報告書形式によって庁内 に配布・公表している。配布先は庁内における職員全員ではなく報 告担当者等の一部の職員に限られている。報告は多くて一年に一回 程度が一般的である。

\section{5. 省エネ・省資源管理システムの谱筑・運用時における落察}

5.1 省エネ・省資源管理システムの箱築・䢮用時における障害

3 次調査の結果を受けて省エネ・省資源管理シスデムの棈筑・運用 時に発生する課題・問題点の要因となる各段階における障害を考察 した。基本的には、省エネ・省資源管理システムを実施する上で、 統括的権限をもち、かつ専門的な組織がないことと、施設数の数が 非常に多く、かつそれらが複数部署間にわたっていることに起因し ていた。以下に各段階における障害を示す。

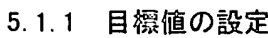

目標値の設定においては一般的に各施設の詳細なデータが把握さ れていないためにそれを基に各自治体が独自の目標值を設定するこ とが园難になっている。そのために現状では国や都道时県の数值目 標を参考·引用せざるを得ない。

\section{1 .2 实施㷋況の把幄}

実施状況の把握の中でも特に数值データの把握に関しては現在多 くの自治体では経費の支出データを基に把握している。そのために 諸施設単位による数値データの把握が所轄部局単位による把握と比 較して困難であり、多くの場合施設単位による把握が成されていな い。

\subsection{3 目漂達成状況の確認}

目標達成状況の確認として、全保有施設単位による現状集計は行 われているが諸施設の診断までには至っていない。そのために達成 状況の確認がそれ以降のシステム運用に有効に譏能しにくくなって いる。これは主に膨大な諸施設の詳細な診断分析を行う専門組識が 存在しないことによる。

5.1 .4 診断結哭のフィードバック

現段階では現状の集計報告が目標であるために、その集計内容が 上層部などの一部の職員にのみ伝達されている。また、その集計結 果に権限が無いために次の環境行動に結びついていない。

\section{2 障害に対する解消手段}

以下に各段階における障害を解消する組識体制上の手段および数 值ブータの流れに関連した手段の考察を示す。

\section{2 .1 組識佮制上の手段}

・システム運用の責任を明確化すると共に、数值データの把握、集 計、分析 (診断)、改善案の作成等の業務を適切かつ効率化する ために、専門統括組織を設立する。またシステム運用の実効性を 高めるために管理上の統括的権限を強化する

・諸施設単位における担当職員と管理権限・責任を明確化する

\subsection{2 数倌データの流れに関通する手段}

・部署ごとではなく諸施設単位におけるデータを整理する

・主観的な行動チェックのみではなく、各施設ごとに実データとそ の分析結果に基づいた、目標値に対する診断を行う

・分析結果（診断結果）を一部担当者のみではなく幅広く伝達（フ イードバック) する

\section{1 まとめ}

本研究では、全国の地方自治体における保有施設の運用時におけ る「省エネ・省資源管理システム」の構築状況とその方法、および 構築する際の課題について調查した。以下に得られた知見を記す。

（1）全国人口 10 万人以上の地方自治体に対して省エネ・省資源に関 する取り組みや省エネ・资源管理システムの構築状況を把握す るためにアンケート調查を行った。シスデムの構築状況は有効 回答（約 50\%）の約 7\%の自治体で既に何等かの形で構築され、 $9 \%$ 自治体で構築中・検討中であった。実施状況は、庁舎施設 では $36 \%$ 自治体で何等かの取り組みが行われているが、その 他の用途の施設では $20 \%$ 前後であった。そして、どの施設用途 においても「目標值の設定」、「データの把握」、達成状況の確 認」の実施割合は半減していた。また、管理項目では電力の使 用量が全体的に実施割合が高く、廃暂物排出量の「データ把握」 と「達成状況の確認」の割合が低かった。

（2）1次調查の結果から、現状ではまだまだ「省エネ・省資源管理シ スデム」が構築および赛施されていないことがわかった。そこ で「省エネ・省資源管理システム」における課題や問題点を検討 するために、比較的実施されている 23 自治体に、アンケート形 式による 2 調査を実施した。その結果、「省エネ・省資源管理シ ステム」自体は有効であるが、施設が複数部局間に分かれてい ることによる組織上の問題点や数値データの把握が困難である 
こと、また、管理項目の設定とその目標值の設定が困難である ことがわかった。

（3）「省エネ・省資源管理システム」の手法とその課題や問題点をよ り明確にすることと、改善点を考察するために、「省エネ・省資 源管理システム」が調查自治体の中で先進的に奏施されている 5 自治体に対してヒアリング調査を実施した。その結果、多くの 自治体では、環境保全課等が事務局を担い、部署（部・課等） ごとに担当者を設置し、定期的にチェックシートを提出させる 方法をとっていた。チェックシートの内容は行動項目の出来不 出来を主観的に評価するものと、部署内関連施設の数值デー夕 （消費量・排出量）を記入するものの 2 つであった。それらの チェックシートは事務局で整理・集計した上で報告書形式等で 報告されていた。

（4）ヒアリング調查の結果、「省エネ・省資源管理シスデム」の障害 は、施設数の数が非常に多いことと、それらが複数部署間にわ たっていることに起因していた。組織的には管理の統括的権限 をもち、かつ専門の組織がないために、各施設の実状に合った 目標值の設定とデータ集計作業が労力的に困難であるし、デー タの診断も集計・報告にとどまり各施設の実効を伴う次の行動 に結びついていない等の問題があった。また、データの集計も 部署ごとの担当者にまかされており、各施設ごとの実状データ が把握しずらい等の問題があった。

地方自治体の諸施設における「省エネ・省資源管理システム」は 構築が始まった段階ではあるが、地方自治体の諸施設の省エネ・省 資源管理は社会的に重要な意義を持つものである。今後、施設数の
数が非常に多く、かつそれらが複数部署間にわたる地方自治体の諸 施設の管理手法に関寸る研究が望まれる。

\section{謝辞}

調查に御協力いただきました自治体の関係各位に感謝の意を表し ます。

\section{参考文献}

1. 環境配庵型官庁施設計画指針、建設大臣宫房官庁営繒部、建設省 III 記者 発表資料、1998

2. 国ひ事業者・消費者としてい環境保全に向けた取組ひ率先実行ひたぬひ行 動計画、環境庁企画調整局環境計画課、渨境庁 III、1998

3. 日本工業新開：自治体における環境管理·監查ひ導入について、環境自治 体、月刊地球環境臨時增刊号、p14-19、1998

1. IBI:C No.98 Vol.17-5 特集 ISO（国際標準化機構）U活動、(財)住宅・建 築 省エネルギー機構、1997.1

5. 環境管理システム研究会：自治体における環境くネジメントシスラムの対 态動向 一平成 9 年度ヒアリン攵調查（福岡県）一、九州大学工学部付属 環境システム科学研究センター、1996.6

6. 世田谷区環境行動指針、世田谷区環境部環境課、1997

7. 世田谷区環境基本計画 - 環境行動指針 一第一次評価・点検報告書一、世 田谷区環境部環境課、1998

8. 箕面市快適環境つくくり計画、箕面市環境保全課、1998 9. 平成 10 年度普及版上越市環境基本計画、上越市生活環境課、1998 